Total Cure 



\title{
Total Cure
}

The Antidote to the Health Care Crisis

\author{
Harold S. Luft
}

Harvard University Press

Cambridge, Massachusetts

London, England

2008 
Copyright (๑) 2008 by the President and Fellows of Harvard College All rights reserved

Printed in the United States of America

Some of the ideas incorporated in the SecureChoice proposal appeared in Harold S. Luft, "Universal Care Coverage: A Potential Hybrid Solution," Journal of the American Medical Association 297 (2007): 1115-1118. Copyright $\odot$ 2007, American Medical Association. All rights reserved.

A Caravan book. For more information, visit www.caravanbooks.org.

Library of Congress Cataloging-in-Publication Data

Luft, Harold S.

Total cure : the antidote to health care crisis / Harold S. Luft. p. cm.

Includes bibliographical references and index.

ISBN 978-0-674-03210-1 (alk. paper)

1. Health care reform-United States. 2. Medical policy-United States. 3. Health planning-United States. 4. Insurance, Health-United States. I. Title.

[DNLM: 1. Health Care Reform-methods-United States.

2. Health Policy—United States. 3. Insurance, Health-United States. WA 540 AA1 L8955t 2008]

RA395.A3L82 2008

362.1'04250973—dc22 2008016220 
To Lori

... and to all who need a better health care system 
